Volume 11 | Issue 3

July 2020

\title{
Book Review: Structures of Indifference: An Indigenous Life and Death in a Canadian City
}

Krista Stelkia

Simon Fraser University, Canada, kms16@sfu.ca 


\title{
Book Review: Structures of Indifference: An Indigenous Life and Death in a Canadian City
}

\begin{abstract}
The case of Brian Sinclair, a First Nations man who died in a Winnipeg, Manitoba, hospital emergency room in 2008 after waiting 34 hours for medical care to treat a preventable infection, represents the degree to which structural indifference exists within Canadian society. This article reviews the book Structures of Indifference: An Indigenous Life and Death in a Canadian City by Mary Jane Logan McCallum and Adele Perry, published by University of Manitoba Press in 2018. The review will provide a content summary of each chapter along with an assessment of the strengths and weaknesses of the book. A critical analysis of how the authors examined this case, using a place-based approach of the city, the hospital, and life and death of Brian Sinclair, is discussed. The review will identify critical concepts and lessons relevant to the development of Indigenous health policy and practice, which will be applicable to both a national and international audience.
\end{abstract}

\section{Keywords}

Structural racism, Indigenous health, settler colonialism, Canadian health care system

\section{Creative Commons License}

(1) (1) $\Theta \Theta$

This work is licensed under a Creative Commons Attribution-Noncommercial-No Derivative Works 4.0 License. 


\section{Book Review: Structures of Indifference: An Indigenous Life and Death in a Canadian City}

\section{McCallum, M., \& Perry, A. (2018). Structures of indifference: An Indigenous life and death in a Canadian city. University of Manitoba Press. 192 pp. $\$ 17.95$ (paperback). ISBN: 978-0- 88755-835-1.}

Structures of Indifference: An Indigenous Life and Death in a Canadian City examines the life and death of Brian Sinclair, a First Nations man who died in 2008 in a Winnipeg, Manitoba, hospital emergency room after waiting 34 hours for medical care to address an easily treatable infection. In reviewing a detailed timeline of events leading up to the death of Brian Sinclair, McCallum and Perry provide an empirical and historical analysis of the city, the hospital, and the life of Brian Sinclair. The authors focus on the experiences and treatment of Indigenous Peoples in settler spaces within Canadian colonial society, including how the legal system views Indigenous deaths through the omission of influential mitigating factors such as racism, colonialism, and structural indifference.

Structures of Indifference is 192 pages with an introduction, three main chapters (titled the City, the Hospital, and Brian Sinclair), and a conclusion. The introduction, titled Thirty-Four Hours, situates the life and death of Brian Sinclair in the context of historical and ongoing settler colonialism. The authors examine the 34 hours leading up to Brian Sinclair's death by recounting a timeline of events from the moment he arrived at the Health Sciences Center (HSC) emergency department in Winnipeg, Manitoba, at 2:53 p.m. on September 19, 2008, to the time he was pronounced dead at 12:51 a.m. on September 21, 2008. Chapter 1 provides a detailed examination of the history of Winnipeg, Manitoba, from pre-settler contact to the present day. The chapter begins with a historical account of the Anishinaabeg and Cree ancestral lands on which Winnipeg is located and then moved into an empirical review of the rise of eighteenth and nineteenth century settler colonialism in the area. The authors describe the geographical segregation of First Nations and Métis peoples from settler societies, and they recount the growing urbanization of First Nations moving from reserves to urban Winnipeg post-1951. From a historical perspective, they highlight how racism and discrimination have become a major part of life in Winnipeg, both through interpersonal and systemic accounts.

Chapter 2 describes the history of Winnipeg's HSC, where Brian Sinclair sought medical treatment that he ultimately did not receive, resulting in his death. In reviewing the case, the authors argue that these events cannot be understood without examining the historical context and experiences of Indigenous people accessing the health care system in the province. The authors provide a historical account of the evolution of the racially segregated health care system that exists in Manitoba: Where settler populations received the latest modern medicine, while Indigenous people were systematically excluded and received substandard care. The chapter concludes by discussing how hospital institutions across Canada have been shaped and influenced by settler colonialism, which is an integral part of understanding the racist ideologies, indifference, and discriminatory societal structures Brian Sinclair faced when he entered HSC for treatment that day.

Chapter 3 focuses on the person at the center of this tragedy, Mr. Brian Sinclair. The authors share the story of who Brian Sinclair was, provide an overview of his life, and demonstrate how far the racist and discriminatory assumptions made by hospital staff were from the true Brian Sinclair known to his family, friends, and community. For instance, several hospital staff at HSC falsely assumed Mr. Sinclair was

Published by Scholarship@Western, 2020 
intoxicated and homeless. Furthermore, his presence in the emergency room was assumed to be solely because he was sleeping off his intoxication (Brian Sinclair Working Group, 2017). Browne et al. (2016) stated, the "colonizing image of the 'drunk Indian' is one of the most harmful stereotypes operating in health care settings” (p. 3). These harmful stereotypes and assumptions continue to permeate the lived realities of Indigenous people who access health care services and are a demonstration of how structural and lethal racism continues to manifest within settler colonial societies. The chapter concludes by countering the false assumptions made about Mr. Sinclair by sharing accurate and factual details about his life.

The book concludes by reflecting on the 10 years since the passing of Brian Sinclair and how similar injustices continue to happen in hospitals, schools, courtrooms, jails, and other colonial spaces across the Canadian State. The authors argue this is a continued demonstration of the colonial violence and devaluation of Indigenous lives that persists in settler colonial spaces, such as hospitals, which are mandated to help, but instead commonly become places of indifference, racism, and death for Indigenous people.

A distinctive strength of this book is the way McCallum and Perry take a place-based historical approach, grounded in a critical anti-colonial lens, to contextualizing the life and death of Brian Sinclair. The authors' backgrounds as historians is a strength in this work that is revealed in the depth and detail of the historical analysis, which is very compelling. For example, when examining the history of the hospital, the authors go back to the original title deed and transfer of land on which HSC was founded, which showed that the very existence of the hospital relied on the transfer of Indigenous Land. Furthermore, a critical examination of the settler doctors, nurses, businessmen, military personnel, and donors whose names brand the HSC buildings and the streets that surround it paint a picture of the city's Indigenous and colonial history. The inclusion of supporting visuals, such as photos and maps, helps to orient the reader to the space of Winnipeg and HSC. Taking a place-based historical approach aids the reader in the realization that these histories and events cannot be examined in silos. McCallum and Perry state, "When we separate the history of people like Brian Sinclair and institutions like the HSC and cities like Winnipeg from the wider history of the dispossession of Indigenous people and land, we radically misunderstand and underestimate the context—-the structures — that shape our lived experiences" (p. 14). The authors demonstrate how the amalgamation of the historical, political, and social environment of HSC, the city of Winnipeg, and the overall Canadian State are integral factors in examination of the tragic death of Brian Sinclair.

The existence of racism and discrimination against Indigenous Peoples when accessing health care has been well documented across various points of the health care system (Allan \& Smylie, 2015; Boyer, 2017; Boyer \& Bartlett, 2017; Browne \& Fiske, 2001; Browne et al., 2011; Furniss, 1999). Approximately $24 \%$ of First Nations adults in Canada have reported being discriminated against in the last 12 months (First Nations Information Governance Centre, 2018). Furthermore, a 2017 Ipsos public affairs survey of the Canadian College of Health Leaders found that, out of 225 health organizations, $51 \%$ reported that anti-Indigenous racism existed within their organization (Richardson \& Murphy, 2018). An important strength of this book is the explicit focus on examining structural levels indifference, racism, and colonial violence within Canadian society. Rather than solely focusing on interpersonal racism and the acts of the service providers who ignored Brian Sinclair, which lead to his death, the authors take a broader focus on examining how structural racism and indifference continues to impact the everyday 
lived experiences of Indigenous Peoples in Canada. While the primary focus of the book is on the health care system, the authors also demonstrate how structures of indifference towards Indigenous Peoples manifest across various domains including the criminal justice, media, and child welfare systems. Importantly, the points raised in this book help to focus attention on the broader societal issues that allow structural inequities to exist within Canada. Overall, McCallum and Perry provide a wellresearched and evidence-based narrative that unpacks the ways in which settler colonialism and racism continue to permeate Indigenous life and death in Canadian cities. Although the book is only 192 pages, the content-heavy chapters provided a rich source of information on the themes outlined by the authors. Key arguments are amply supported with empirical literature and are discussed in a way that is digestible to a non-Indigenous health-specialist audience, while still providing a valuable perspective for the broader public health, policy, or health practitioner community.

Despite the detail that went into describing the city and the hospital, a criticism of this book is the lack of detail about the life of Brian Sinclair. In fact, the chapter on Brian Sinclair is one of the shortest chapters in the book. Given the notoriety of this case, I appreciated the authors dedicating a chapter to the person at the center of this tragedy. While the authors clearly state that they relied on "twenty-first century colonial records available in libraries and online, namely newspapers and the records associated with the inquest into Brian Sinclair's death" (p. 106), the chapter would have been further strengthened with quotes and stories from interviews with his family. In addition, the authors failed to provide recommendations on potential solutions to address structural indifference and racism. While there was a strong emphasis on examining history and the role of colonialism when analyzing such cases, supplementing the chapters with recommendations on how best to move forward in Indigenous policy, practice, and research would have further strengthened the content of the book.

This book accomplishes its overarching goal of showcasing, through the Brian Sinclair case, the ongoing impacts of settler colonialism and indifference on the lives of Indigenous Peoples in settler spaces. The authors bring focus and attention to the role of history, racism, and colonization in understanding Mr. Sinclair's case and others like it. This is critically important because in trying to understand the cause of death and how they could have been prevented a number of inquests and inquiries into deaths of Indigenous people have omitted or refused to put racism and colonialism on the public record (Razack, 2015). As discussed briefly in the book, the inquest into Mr. Sinclair's death primarily focused on failed triage procedures and policies in the HSC emergency department and did not examine the broader issue of racism and discrimination (Brian Sinclair Working Group, 2017). Therefore, McCallum and Perry provide an alternative viewpoint that shows how structural indifference, racism, and settler colonialism were central issues surrounding Mr. Sinclair's death. This perspective is important to further advance meaningful reconciliation in Canada because denial about our colonial history and its continued impact on the health and well-being of Indigenous Peoples still exists (Browne, 2017; Henry \& Tator, 2010; Loppie-Reading \& Wien, 2013; McGibbon \& Etowa, 2009). We continue to witness discourses of denial and racist rhetoric across Canadian society, including by those who hold positions of power in government. A recent example is that of Senator Lynn Beyak, who was suspended from the Senate of Canada in 2019 and again in 2020 for refusing to remove letters that were overtly racist toward First Nations from her website, citing the benefits of the Indian Residential School System and promoting the idea that Survivors had a positive experience in these schools, despite overwhelming evidence to the contrary (Joseph, 2019; Mosby, 2013; Office of the Senate Ethics Officer, 2019; Tasker, 2019, 2020; Truth and Reconciliation Commission of Canada, 2015). Denial is an integral factor in maintaining the 
pervasiveness of racist ideology and can lead to the justification by members of society, governments, and organizations that no action is required and the status quo remains (Henry \& Tator, 2010). Therefore, the perspectives of McCallum and Perry are integral in exposing the impact of settler colonialism on the lives of Indigenous people and helping to make more meaningful advancements towards reconciliation.

There has been a concerted effort nationally to try and address racism in response to the Truth and Reconciliation Commission of Canada's (2015) Call to Action \#24 to provide anti-racism training for students in medical and nursing schools. Over the past five years, medical schools, health professional associations, and universities across Canada have begun to incorporate anti-racism, implicit bias, and cultural safety training into course curricula and professional development with the aim to reduce antiIndigenous racism in the health care system (Richardson \& Murphy, 2018; Vogel, 2019). Furthermore, organizations such as the College of Family Physicians of Canada have developed a guidebook for physicians to understand the role of systemic racism in impacting the health and patient experience for Indigenous Peoples (College of Family Physicians of Canada, 2016). While focusing attention to interpersonal and systemic racism is needed, the perspectives and key issues raised in this book around structural racism and indifference are critically important to make further advancements in the field of Indigenous health policy and practice.

A decade after Brian Sinclair's death in a Winnipeg hospital, Structures of Indifference provides an opportunity to critically examine this unacceptably common case in order to shed light on missed opportunities and lessons learned to better inform future Indigenous health policy and practice. To make advancements in addressing anti-Indigenous racism in the health care system, nationally and internationally, Structures of Indifference provides a much-needed perspective in critically examining the treatment of Indigenous people in institutions mandated to provide medical care and treatment. McCallum and Perry confront the indifference that colonial settler societies have towards Indigenous Peoples and demonstrate the importance of examining Indigenous deaths as intrinsically linked to the ongoing history of colonial violence. A key lesson relevant to Indigenous health policy and practice is that using a placed-based historical approach in examining these cases provides a more comprehensive view into the systemic and structural indifference towards Indigenous Peoples within society. Employing this type of approach will not only lead to the development of more effective Indigenous health policies aimed at preventing and addressing future cases, but it will also begin to hold systems and structures accountable for the death of Indigenous people in colonial institutions (Krieger, 2014; Razack, 2015).

Overall, Structures of Indifference is an important and timely contribution to Indigenous health literature and a valuable resource for scholars, students, policymakers, health care professionals, and health administrators who seek to understand the historical impact of colonization on present-day forms of structural violence and racism against Indigenous Peoples in Canadian society. More broadly, this book adds to a growing body of literature that focuses on structural racism and its impacts on the health and well-being of Indigenous Peoples. If the next generation of Indigenous health policy leaders and practitioners make a collective effort to formally assess the impacts of colonialism on the health of Indigenous Peoples, this will lead towards significant advancements in addressing Indigenous health inequities both nationally and internationally. 


\section{References}

Allan, B., \& Smylie, J. (2015). First Peoples, second class treatment: The role of racism in the health and well-being of Indigenous peoples in Canada. https://www.wellesleyinstitute.com/wpcontent/uploads/2015/02/Summary-First-Peoples-Second-Class-Treatment-Final.pdf

Boyer, Y. (2017). Healing racism in Canadian health care. CMAJ, 189(46), E1408-E1409. https://doi.org/10.1503/cmaj.171234

Boyer, Y., \& Bartlett, J. (2017). External review: Tubal ligation in the Saskatoon Health Region: The lived experience of Aboriginal women. https://www.saskatoonhealthregion.ca/ DocumentsInternal/Tubal_Ligation_intheSaskatoonHealthRegion the Lived_Experience_of Aboriginal Women_BoyerandBartlett_July_22_2017.pdf

Brian Sinclair Working Group. (2017). Out of sight: Summary of the Inquest into Brian Sinclair's Death. https://media.winnipegfreepress.com/documents/Out_of_Sight_Final.pdf

Browne, A. J. (2017). Moving beyond description: Closing the health equity gap by redressing racism impacting Indigenous populations. Social Science and Medicine, 184, 23-26. https://doi.org/10.1016/j.socscimed.2017.04.045

Browne, A. J., \& Fiske, J. (2001). First Nations women's health care services. Western Journal of Nursing Research, 23(2), 126-147. https://doi.org/10.1177/019394590102300203

Browne, A. J., Smye, V. L., Rodney, P., Tang, S. Y., Mussell, B., \& O’Neil, J. (2011). Access to primary care from the perspective of Aboriginal patients at an urban emergency department. Qualitative Health Research, 21(3), 333-348. https://doi.org/10.1177/1049732310385824

Browne, A. J., Varcoe, C., Lavoie, J., Smye, V., Wong, S. T., Krause, M., Tu, D. Godwin, O., Khan, K., \& Fridkin, A. (2016). Enhancing health care equity with Indigenous populations: Evidence-based strategies from an ethnographic study. BMC Health Services Research, 16(1), 544. https://doi.org/10.1186/s12913-016-1707-9

College of Family Physicians of Canada. (2016). Health and health care implications of systemic racism on Indigenous Peoples in Canada. https://www.cfpc.ca/uploadedFiles/Resources/_PDFs/ SystemicRacism_ENG.pdf

First Nations Information Governance Centre. (2018). National Report of the First Nations Regional Health Survey Phase 3: Volume 2. https://fnigc.ca/sites/default/files/docs/fnigc rhs phase 3 volume two en final website $0 . p d f$

Furniss, E. (1999). The burden of history: Colonialism and the frontier myth in a rural Canadian community. University of British Columbia Press.

Henry, F., \& Tator, C. (2010). The colour of democracy: Racism in Canadian society (4th ed.). Nelson Education. 
Joseph, R. (2019, March 29). Lynn Beyak's 'racist' letters are still online-a week after she was ordered to remove them. Global News. https://globalnews.ca/news/5111181/lynn-beyak-racist-letters/

Krieger, N. (2014). Discrimination and health inequities. International Journal of Health Services, 44(4), 643-710. https:// https://doi.org/10.2190/HS.44.4.b

Loppie-Reading, C., \& Wien, F. (2013). Health inequalities and social determinants of Aboriginal Peoples' health. https://doi.org/10.1111/j.1365-2214.2009.00971_2.x

McGibbon, E., \& Etowa, J. (2009). Anti-racist health care practice. Canadian Scholar's Press Inc.

Mosby, I. (2013). Administering colonial science: Nutrition research and human biomedical experimentation in Aboriginal communities and residential schools, 1942-1952. Histoire Sociale/Social History, 46(1), 145-172. https://doi.org/10.1353/his.2013.0015

Office of the Senate Ethics Officer. (2019). Inquiry report under the Ethics and Conflict of Interest Code for Senators concerning Senator Lynn Beyak. http://sen.parl.gc.ca/seo-cse/PDF/InquiryBeyak2019-e.pdf

Razack, S. H. (2015). Dying from improvement: Inquest and inquiries into Indigenous deaths in custody. University of Toronto Press.

Richardson, L., \& Murphy, T. (2018). Bringing reconciliation to healthcare in Canada. http://www.healthcarecan.ca/wp-content/themes/camyno/assets/document/ Reports/2018/HCC/EN/TRCC_EN.pdf

Tasker, J. P. (2019, May 9). Lynn Beyak suspended from Senate after refusing to take down letters condemned as racist. Canadian Broadcasting Corporation. https://www.cbc.ca/ news/politics/tasker-beyak-ethics-report-1.5129767

Tasker, J. P. (2020, February 27). Lynn Beyak has been suspended from the Senate for a second time. CBC News. https://www.cbc.ca/news/politics/lynn-beyak-suspended-second-time-1.5478536

Truth and Reconciliation Commission of Canada. (2015). Truth and Reconciliation Commission of Canada: Calls to Action. Government of Canada. http://publications.gc.ca/collections/ collection_2015/trc/IR4-8-2015-eng.pdf

Vogel, L. (2019). Medical schools to boost numbers of Indigenous students, faculty. Canadian Medical Association Journal, 191(22), E621-E621. https://doi.org/10.1503/cmaj.109-5753 